\title{
(1732) Proposal to conserve the name Pseudocercospora against Stigmina and Phaeoisariopsis (Hyphomycetes)
}

\author{
Uwe Braun ${ }^{1} \&$ Pedro W. Crous ${ }^{2}$ \\ ${ }^{1}$ Martin-Luther-Universität, FB. Biologie, Institut für Geobotanik und Botanischer Garten, Herbarium, \\ Neuwerk 21,D-06099 Halle (Saale), Germany.uwe.braun@botanik.uni-halle.de (author for correspon- \\ dence) \\ ${ }^{2}$ Centraalbureau voor Schimmelcultures, Fungal Biodiversity Centre, P. O. Box 85167, NL-3508 AD Utrecht, \\ The Netherlands.
}

(1732) Pseudocercospora Speg., Anales Mus. Nac. Hist. Nat. Buenos Aires 20: 438. 1910 [Fungi], nom. cons. prop.

Typus: P. vitis (Lév.) Speg.

$(=\quad$ Stigmina Sacc., Michelia 2: 22. $1880[$ Fungi], nom. rej. prop.

Typus: S. platani (Fuckel) Sacc.

$(=\quad$ Phaeoisariopsis Ferraris, Ann. Mycol. 7: 280. 1909 [Fungi], nom. rej. prop.

Typus: P. griseola (Sacc.) Ferraris.

Mycosphaerella Johanson (Mycosphaerellaceae Lindau), which is one of the largest genera of ascomycetes, produces a wide range of coelomycetous and hyphomycetous anamorphs (Crous \& al. in Stud. Myol. 45: 107-121. 2000; Verkley \& Priest in Stud. Mycol. 45: 123-128. 2000; Crous \& al. in Stud. Mycol. 50: 195-214), including cercosporoid hyphomycetes as largest group. A recently issued check-list of names published in Cercospora Fresen. and Passalora Fr. comprises in total 5720 names (Crous \& Braun in CBS Biodiversity Series 1: 1-571. 2003). During the course of recently carried out monographic studies of cercosporoid Mycosphaerella anamorphs, based on molecular (PCR) examinations as well as reassessments of morphological characters and differences in the conidiogenesis, it was realized that the number of hyphomycetous anamorph genera in this complex could be reduced drastically (Crous \& al. in Mycologia 93: 1081-1101. 2001). The traditional separation of the genera concerned turned out to be arguably untenable since conidiogenesis and structure of the conidiogenous loci and conidial hila are barely distinct. Recently accomplished detailed examinations focusing on Phaeoisariopsis griseola, the type of Phaeoisariopsis, and Stigmina platani (Crous \& al. in Stud. Mycol. 55: 163-173. 2006), the type of Stigmina, revealed that the species concerned clustered together with Mycosphaerella taxa having Pseudocercospora anamorphs, and specifically with $P$. vitis, the type of Pseudocercospora. Re-examinations of numerous collections, including type material, led to a reassessment of the morphology, conidiogenesis and structure of the conidiogenous loci, showing that the taxa concerned are congeneric with Pseudocercospora (Crous \& al. in Stud. Mycol. 55: 163-173. 2006). Deighton (in Mycol. Res. 94: 1096-1102. 1990) confined Phaeoisariopsis to a few taxa around the type, P. griseola, reallocated most other species to Passalora and Pseudocercospora, and questioned the taxonomic value of synnematous conidiomata at the generic level, which was subsequently shown to be unreliable as a generic feature in the Mycosphaerellaceae based on molecular data. Sutton \& Pascoe (in Mycol. Res. 92: 210-222. 1989) restricted Stigmina to a few foliicolous taxa close to the type, S. platani, characterized by having sporodochial conidiomata, percurrently proliferating conidiogenous cells and distoseptate conidia. Percurrent conidiogenous cells and the structure of the conidiogenous loci are in agreement with the current concept of Pseudocercospora, and the formation of distosepta proved to be of no use in Mycosphaerella anamorphs for the discrimination of genera (Crous \& al. in Mycologia 93: 1081-1101. 2001; Crous \& al. in Stud. Mycol. 50: 195-214).

Thus, it is inevitable that Stigmina, Phaeoisariopsis and Pseudocercospora be merged. Stigmina is the earliest legitimate name for the large genus in its new circumscription (Crous \& al. in Stud. Mycol. 55: 163-173. 2006). However, as discussed above, Stigmina as well as Phaeoisariopsis comprise in the present circumscription only a few taxa around the respective types of these generic names, whereas the generally recognised genus Pseudocercospora embraces 1171 taxa (Deighton in Mycol. Pap. 140: 1-168. 1976; Yen \& Lim in Gard. Bull., Singapore, 33: 151-263. 1980; Hsieh \& Goh, Cercospora and similar fungi from Taiwan: 1-376. 1990; Guo \& Hsieh, The genus Pseudocercopsora in China. Mycosystema Monographicum Series 2: 1-388. 1995; Shin \& Kim, Cercospora and allied genera from Korea. Plant Pathogens of Korea 7: 1-301. 2001; Crous \& Braun in CBS Biodiversity Series 1: 1-571. 2003). Therefore, to avoid the introduction of more than 1000 new combinations and to maintain the well-known name Pseudocercospora, which contains a very large number of important plant pathogens that are widely distributed, we propose conservation of the latter name against the names of the smaller genera Stigmina and Phaeoisariopsis. The proposed rejection of this last name will cause the loss of the name Phaeoisariopsis griseola, referring to an important plant disease of bean, well-known and widespread in the phytopathological literature. However, the strong advantages of rejecting Phaeoisariopsis in favour of Pseudocercospora are obvious. 